\title{
PERJANJIAN KERJA ANTARA ATLET SEPAKBOLA PROFESIONAL DENGAN KLUB SEPAKBOLA
}

\author{
Oleh : \\ Yola Zulva Janika*, Mashudi** \\ *Mahasiswa Fakultas Hukum Universitas Gresik \\ **Dosen Fakultas Hukum Universitas Gresik \\ Email: \\ Mashudiunigres@gmail.com \\ yolazulvajanika@yahoo.com
}

\begin{abstract}
ABSTRAK
Dalam klausul kontrak pemain sepakbola profesional dengan klub sepakbola secara eksplisit mencantumkan bahwa kontrak pemain sepakbola bersifat khusus dan tidak tunduk pada Undang-Undang Nomor 13 Tahun 2003 tentang Ketenagakerjaan dan atlet sepakbola profesional mempunyai hukum yang khusus yaitu Lex sportiva.Kontrak kerja pemain sepakbola profesional tunduk pada Undang-Undang Nomor 3 Tahun 2005 tentang Sistem Keolahragaan Nasional. Undang-Undang Nomor 3 Tahun 2005 tentang Sistem Keolahragaan Nasional merupakan Lex Specialis dari Undang-Undang Nomor 13 Tahun 2003 tentang Ketenagakerjaan. Dalam ketentuan FIFA penyelesaian sengketa yang terjadi antara atlet sepakbola profesional dengan klub dapat di selesaikan melalui Arbitrase yang telah disediakan oleh induk organisasi sepakbola tersebut.
\end{abstract}

Kata kunci : Hukum Olahraga (Lex Sportiva); Ketenagakerjaan; Mekanisme Penyelesaian Sengketa; Perjanjian.

\footnotetext{
ABSTRACT

A number of legal experts argued that the Act No. 13 year 2003 about the Employment contract applicable to professionalhu athletes because of the professional athlete is the workers/labourers and applies the provisions of the Act such. However, in the professional soccer player contract clause with the football club to explicitly specify that the special nature of player contracts and are not subject to law No. 13 Year 2003 about the employment and soccer athletes professionals have special laws i.e. Lex sportiva. Professional soccer player employment contract subject to the provisions of Act No. 3 Year 2005 about National Sport System. Act No. 3 of the year 2005 of the national Sport System is Lex Specialists of law No. 13 Year 2003 concerning Employment. In terms of the FIFA dispute that took place between professional athletes with the Club can resolve through arbitration that has been provided by the parent organization of the football.

Keywords : Sports Law( Lex Sportiva); Employment; The Dispute Settlement Mechanism; Contract.
} 


\section{A. PENDAHULUAN}

Saat ini, olahraga bukan sekedar menggerakkan badan, tetapi juga mampu menggerakkan roda ekonomi. "Perkembangan olahraga di indonesia, akan jauh lebih efektif, bila mendapat sentuhan dari sisi pemasaran kepada masyarakat dan dunia industri. Secara ekonomi perputaran uang di dalam industri keolahragaan cukup besar terutama kepada setiap atlet-atlet yang memiliki prestasi di bidang olahraganya masing-masing". ${ }^{1}$

Seorang atlet harus bisa memahami dalam beraudiensi dengan pihak manajemen klub ataupun induk organisasi olahraga yang menginginkan mereka bermain atas nama klub ataupun atas nama negara. Hal yang harus dipahami terutama mengenai hak dan kewajiban yang harus sama-sama dipahami oleh para atlet dan pihak klub. Seperti dalam hal telatnya atau menunggakya gaji pemain. Sebenarnya dalam hal ini para pemain bisa mengadukan masalahnya ke pihak kepolisian atau pihak pengadilan untuk mendapatkan haknya.

Seperti contohnya pemasalahan sistem kontrak pemain sepakbola di tanah air saat ini dilakukan dengan sistem kekeluargaan. Jadi pembayaran gaji kepada para atletpun dilakukan dengan kekeluargaan. Maka untuk mampu menjadi atlet profesional dan berprestasi atlet tersebut harus pandai memahami kontrak kerja yang dia sepakati dan mampu bersikap tegas.

Hal mendasar sering terjadinya permasalahan kontrak kerja antara atlet sepakbola profesional adalah kurangnya perlindungan hukum terhadap atlet sepakbola dan kurangnya

1 Memet Muhammad, Momon Sudarman, . dan Ujang Sudrajat. sport marketing, Yogyakarta, 2016, h.18. pemahaman atlet terhadap hak-haknya yang terdapat dalam kontrak kerja. Peran hukum disini sangat penting karena berkaitan dengan terjaminnya hak-hak yang dimiliki oleh pemain sepakbola profesional.

Kemudian mengenai forum penyelesaian sengketa hubungan kerja antara atlet dengan klub profesional juga bermasalah dan sedikit unik. Jika kita merujuk pada Undang-Undang Nomor 22 Tahun 2004 tentang penyelesaian perselisihan hubungan industrial, maka permasalahan gaji buruh yang tertunggak di selesaikan di Pengadilan Hubungan Indrustrial sedangkan jika diselesaikan melalui arbitrase tidak semua sengketa dapat diselesaikan melalui arbitrasi, hanya perselisihan antara serikat pekerja/serikat buruh dalam satu perusahaan yang dapat diselesaikan melalui jalur arbitrase.

Berdasarkan latar belakang diatas maka penulis tertarik untuk membahas mengeni "Perjanjian Kerja Antara Atlet sepakbola profesional Dengan Klub sepakbola".

\section{B. METODE PENELITIAN}

Didalam penelitian ini penulis menggunakan metode penelitian yuridis normatif yaitu dilakukan dengan cara menelaah teori-teori hukum, konsep-konsep hukum, asasasas hukum serta mengkaji peraturan perundang-undangan yang berhubungan dengan pokok permasalahan yang telah dirumuskan dalam penelitian ini. Untuk mencari jawaban atas pokok permasalahan dalam penelitian ini, penulis menggunakan tiga pendekatan masalah yaitu Pendekatan Perundang-undangan (Statute Approach), Pendekatan Konseptual (Conceptual Approach), 
Pendekatan

(Comparative Approach).

\section{PEMBAHASAN}

\section{Atlet Sepakbola Profesional}

Dalam sepakbola yang terus melalui perbaikan pengembangan, sepakbola di era masa kini tidak hanya menjadikan olahraga ini sebagai hobi, olahraga ini telah menjadi sebuah hiburan tontonan atau lahan industri di dunia olahraga yang menjadikan pemain sepakbola sebagai profesi atau tenaga kerja pada klub yang melalui perekrutan hingga perjanjian kontrak kerja.

Setiap orang dapat menjadi olahragawan profesional setelah memenuhi persyaratan diantaranya yaitu pernah menjadi olahragawan amatir yang mengikuti kompetisi secara periodik, memenuhi ketentuan ketenagakerjaan yang dipersyaratkan, menuhi ketentuan medis yang dipersyaratkan, dan memperoleh pernyataan tertulis tentang pelepasan status dari olahragawan amatir menjadi olahragawan profesional yang diketahui oleh induk organisasi cabang olahraga yang bersangkutan.

Dalam klub sepakbola perekrutan pemain adalah hal yang paling penting guna mendapatkan pemain yang dibutuhkan untuk tujuan atau target klub. Adapun ketentuan FIFA yang tertuang dalam FIFA Ragulation for the Status and transfer of player, PSSI berhak membuat dan memiliki sistem status, alih status, dan perekrutan pemain.

FIFA atau PSSI berwenang dalam tata cara perekrutan yang dilakukan oleh setiap klub. Rekruitmen dilaksanakan dengan dasar aturan atau tata cara yang telah ditetapkan FIFA atau PSSI. Pihak klub yang akan merekrut pemain profesional dapat melalui pemain itu sendiri atau agen dengan klub. Maka langkah selanjutnya adalah para pihak menjalin sebuah kerja sama dalam bentuk kontrak/ perjanjian kerja. Pemain profesional yang terikat perjanjian kerja dengan pihak klub profesional berkewajiban mengikuti aturan yang diberlakukan dari awal kesepakatan pelaksanaan sampai dengan berakhirnya kontrak oleh kedua pihak tersebut.

\section{Perjanjian Kerja Atlet Sepakbola Profesional dengan Klub Sepakbola}

Berdasarkan Pasal 1 angka 14 Undang-Undang Ketenagakerjaan, perjanjian kerja adalah "perjanjian antara pekerja/buruh dan pengusaha atau pemberi kerja yang membuat syarat-syarat kerja, hak dan kewajiban kedua belah pihak". ${ }^{2}$ Menurut Imam Soepomo bahwa, "perjanjian kerja adalah suatu perjanjian dimana pihak kesatu (buruh), mengikatkan diri untuk bekerja dengan menerima upah dari pihak kedua yakni majikan dan majikan mengikatkan diri untuk memperkerjakan buruh dengan membayar upah". ${ }^{3}$ Perjanjian kerja pemain sepakbola profesional dengan klub sepakbola di Indonesia tentunya harus memperhatikan buku III KUHPerdata, sebagai dasar dalam membuat suatu perjanjian. Perjanjian atau "overeekomst" merupakan "salah satu sumber perikatan (selain UndangUndang) karena para pihak mempunyai kebebasan untuk mengadakan segala

${ }^{2}$ Lalu Husni, Pengantar Hukum Ketenagakerjaan Indonesia, Grafindo, Jakarta 2006, h 54.

3 Zaeni Asyhadie,Hukum Kerja Hukum Ketenagakerjaan Bidang Hubungan Kerja, Raja Grafindo Pustaka, Jakarta, 2007, h.53. 
jenis perjanjian sepanjang tidak bertentangan dengan Undang-Undang, kesusilaan, dan ketertiban umum". 4

\section{Pasal $1313 \quad$ KUHPerdata} membahas mengenai definisi perjanjian yakni "perjanjian adalah suatu perbuatan dimana satu orang atau lebih mengikatkan diri terhadap satu orang atau lebih". 5 Artiya, dalam perjanjian tersebut terdapat hak dan kewajiban dari para pihak untuk melaksanakan kegiatan sebagaimana yang telah disepakati dan tertera dalam perjanjian yang biasanya dirumuskan dalam satu kontrak.

Berdasarkan pemahaman diatas menandakan bahwa perjanjian kerja atlet sepakbola profesional dengan klub sepakbola di Indonesia mengacu dan memenuhi ketentuan Pasal 1320 KUHPerdata tentang syarat sahnya suatu perjanjian. Pertama, sepakat bagi mereka yang mengikatkan dirinya. Artinya pemain sepakbola profesional dan klub sepakbola tersebut telah sepakat mengenai hak dan kewajiban yang muncul dalam perjanjian kerja tersebut, seperti jumlah gaji pemain, jangka waktu kontrak kerja tersebut, bonus loyalty, bonus penampilan, bonus lainnya (apabila klub tersebut mendapatkan gelar juara), sanksi apabila pemain melanggar kontrak, pilihan hukum akan dilanjutkan ke pengadilan apabila timbul sengketa diantara para pihak (keterlambatan gaji, tindakan wanprestasi dari salah satu pihak) dan lain-lain tentunya unsur yang pertama ini penting untuk dipahami oleh kesua belah pihak karena menyangkut hak dan kewajiban diantara kedua belah pihak dalam

${ }^{4}$ Djaja S. Melialala, Hukum Perdata Dalam Perspektif BW, Bandung, Nuasa Aulia, 2012, h. 159.

${ }^{5}$ Ibid. jangka waktu perjanjian atau kontrak kerja yang telah disepakati. Kedua, kecakapan untuk membuat suatu perikatan. Dari rumusan ini tentu dipahami bahwa setiap pemain sepakbola profesional harus cakap untuk membuat suatu perjanjian kerja dengan klub sepakbola. Biasanya, pemain sepakbola diwakili oleh seorang agen untuk bernegosiasi dengan klub dan hal tersebut tentunya tidak menjadi masalah selama agen tersebut telah diberikan mandat oleh pemain tersebut. Ketiga suatu hal tertentu. Rumusan ini sudah jelas bahwa perjanjian kerja harus memuat hal-hal tertentu, dalam perjanjian kerja pemain sepakbola profesional dengan klub sepakbola unsur ketiga ialah berkaitan dengan jasa, yakni keahlian pemain sepakbola untuk bertanding dan membawa klub yang mengontraknya menjadi juara dikompetisi yang mereka ikuti. Keempat, sebab yang halal. Artinya, perjanjian yang dibuat pemain sepakbola profesional dengan klub sepakbola di Indonesia tidak boleh bertentangan dengan Undang-Undang, kesusilaan, dan ketertiban umum.

Ketentuan lain yang harus dipahami adalah "mengenai asas-asas dalam pembentukan perjanjian, terutama asas kebebasan berkontrak yang berhubungan dengan isi perjanjian, yaitu kebebasan menentukan "apa" dan dengan "siapa" perjanjian itu diadakan". 6 Asas ini tercantum pada Pasal 1338 ayat (1) KUHPerdata yang menyatakan bahwa, "Semua perjajian yang dibuat secara sah berlaku sebagai Undang-Undang bagi mereka yang membuatnya." Asas kebebasan berkontrak meliputi

6 Subekti, Hukum Perjanjian, Jakarta, 2005, h. 15. 
kebebasan setiap orang untuk memutuskan apakah membuat perjanjian atau tidak membuat perjanjian, kebebasab para pihak untuk memilih dengan siapa akan membuat perjanjian, kebebasan para ihak untuk menentukan bentuk perjanjian, kebebasan para pihan untuk menentukan isi perjanjian, dan kebebasan para pihak untuk menentukan cara pembuatan perjanjian termasuk dalam perjanjian standar yang cara pembuatannya telah ditentukan oleh salah satu pihak.

Selain itu, dalam asas ini meliputi juga kesepakatan para pihak dalam suatu perjanjian untuk memilih yurisdiksinya dan pilihan hukum yang berlaku sebagaimana dimaksud dalam Pasal 1338 KUHPerdata. Hikmahanto Juana, selaku pakar hukum internasinal berpendapat bahwa, "dalam implementasi dari asas kebebasan berkontrak yang sifatnya universal dalam suatu perjanjian juga tergantung pada posisi tawar menawar (bargaining power) diantara para pihak disuatu perjanjan untuk menentukan keduahal tersebut diatas". 7 Asas kebebasan berkontrak ini menjadi dasar bahwa isi perjanjian kerja antara pemain sepakbola profesional dengan klub sepakbola tergantung pada negosiasi dan kesepakatan kedua belah pihak berkaitan dengan menentukan isi perjanjian mengenai hak dan kewajiban yang muncul dalam perjanjian kerja sebagaimana yang telah disebutkan sebelumnya dibagian syarat sahnya suatu perjanjian, yakni sepakat bagi mereka yang mengikatkan dirinya.

Asas kebebasan berkontrak juga memberikan kebebasan bagi pemain

${ }^{7}$ Albert Aries, "menentukan pilihan hukum saat perjanjian”, 7 Mai 2018, Hukumonline.com, 6 Juli 2019, h. 1. sepakbola profesional dan klub profesional untuk tunduk pada ketentuan suatu hukum tertentu karena perjanjian tersebut berlaku sebagai Undang-Undang bagi mereka yang membuatnya.

Hal ini berkaitan dengan pilihan hukum (choise of law/rechtswahli) dari para pihak untuk dapat memilih sendiri hukum yang harus dipakai untuk perjanjian dengan pembatasan, yaitu sepanjang tidak melanggar ketertiban umum dan tidak boleh menjelma menjadi penyeludupan hukum.

\section{Hukum Olahraga (Lex Sportiva)}

Lex Sportiva pada awalnya mulai di bicarakan pada sekitar tahun 2000. Lex Sportiva adalah sebuah istilah baru yang menjadi perdebatan di kalangan akademisi, bahkan di Indonesia. Lex Sportiva sampai saat ini masih terus berkembang seiring dengan pertumbuhan olahraga itu sendiri. Lex Sportiva dipahami sebagai "sebuah sistem hukum yang tidak berada dalam sistem hukum Internasional, tetapi memasuki wilayah sistem hukum transnasional". 8

Hukum transnasional merupakan "hukum yang terbentuk oleh komunitas internasional dan sebagai konsekuensi sebagai lahirnya a global society yang menghilangkan batas-batas administratif suatu negara dan kemudian melahirkan kesepakatan dan perjanjian kerja sama internasional dalam segala bidang termasuk olahraga, khususnnya kompetisi sepakbola profesional". ${ }^{9}$ Ken Foster menjelaskan bahwa:

8 Hinca panjaitan, kedaulatan negara VS Kedaulatan FIFA dalam kompetensi sepakbola profesional untuk memajukan kesejahteraan umum, (Jakarta; Gramedia Pustaka Utama, 2011), h, 135.

${ }^{9}$ Ibid, h. 79. 
"Global sports law, by contrast, may provisionally be defined as a transnational autonomous legal order created by the private global institutions that govern international sport". It is a sui generis set of principles creted from transnational legal norms generated by the rules, and the interpretation threof, of international sporting federations. This is a saparate legal order that is globally autonomous. This implies that international sporting federation cannot be regulated by national courts or gevorments. They can only be selfregulation by their own internal institution or by external institution created or validated by them. Otherwise, they enjoy a diplomatictype immunity from legal regulation.

Dari pemaparan tersebut, diketahi bahwa lex sportiva adalah peraturan yang dibuat oleh induk organisasi olahraga, yakni setiap anggota organisasi tersebut harus tunduk terhadap statuta organisasi dan aturan lex sportiva memiliki kekuatan mengikat dan memaksa oleh otoritas olahraga dan mereka tidak pernah membutuhkan tindakan resmi negara berdaulat.

Contoh yang kongkret adalah FIFA, sebagai satu-satunya federasi sepakbola internasional yang menaungi asosiasi-asosiasi sepakbola negaranegara seluruh dunia, FIFA memiliki kekuatan untuk menegakkan hukumnya sendiri. Misal, tim nasional dijatuhi sanksi dilarang tampil di kandang sendiri. Maka, negara tidak bisa masuk kedalamnya dan ikut campur untuk membatalkan sanksi tersebut, karena FIFA memiliki kekuatan tersendiri untuk menegakkan aturannya tanpa intervensi dari negara. Ini membuktikan bahwa "adanya para subjek hukum non negara yang memiliki jangkauan pemberlakuan internasional dan diikuti secara internasional pula

Lex sportiva adalah hukum yang khusus mengatur tentang olahraga yang dibentuk oleh institusi komunitas itu sendiri yang bersifat internasional, misalnya "federasi sepakbola profesional FIFA dan berlaku serta ditegakkan oleh lembaga olahraga itu sendiri tanpa intervensi dari hukum positif suatu negara dan tanpa intervensi dari hukum internasioal". ${ }^{10}$ Ken Foster merumuskan bahwa Lex Sportiva as a Global Sport Law adalah sebagai aturan hukum otonom dan independent, yang melintasi wilayah hukum negara, yang diciptakan oleh lembaga-lembaga swasta global, yang mengatur olahraga secara internasional. Karaktristik utama bahwa hukum olahraga global merupakan peraturan kontraktual dengan kekuatan mengikatnya didasarkan pada perjanjian untuk menyerahkan kekusaan dan hak kepada otoritas dan yuridiksi federasi olahraga interrnasional tersebut. Selain itu Lex Sportiva as a Global Sport Law tidak diatur oleh sistem hukum nasional. Lex Sportiva diberlakukan ketentuan legislasi dan konstitusional yang dibuat oleh federasi-federasi olahraga internasional.

"Lex Sportiva memiliki dasar kontraktual formal dan legitimasinya datang dari kesepakatan yang dibuat secara sukarela atau pengakuan kepada yuridiksi dari federasi-federasi olahraga itu sendiri dan dari para atlet dan pihak lain yang berada dibawah

\footnotetext{
${ }^{10} I b i d$, h. 72.
} 
yuridiksinya". ${ }^{11}$ Konsep Lex Sportiva ini menjadi menarik karena 4 alasan utama, yaitu (i) Lex Sportiva merupakan suatu sistem hukum yang global dan transnasinal serta melampaui batas-batas negara, (ii) Lex Sportiva merupakan contoh utama sebagai global legal pluralis, (iii) Lex Sportiva sebagai a pluralis contractual order dan karenanya mempunyai tingkat otonomi yang tinggi, dan (iv) Lex Sportiva merupakan varian dari model penyelesaian sengketa olahraga sebagai a part of a wider "privatization" of sport law which takes issues away from national courts by reference to contractual agreement. ${ }^{12}$

Dari uraian tersebut dapat dilihat bahwa federasi olahraga terutama FIFA mempunyai sistem hukum sendiri yang otonomi dan independen. Bahkan negara sekalipun tidak bisa ikut campur didalamnya. Meskipun harus diakui hukum negara tetap berlaku dan bersinambungan, karena aktivitas olahraga berlangsung dalam wilayah suatu negara. PSSI harus mengikuti tata cara seperti pengamanan pertandingan, perizinan penggunaan stadion, pembentukan klub sepakbola, dan pembentukan asosiasi sepakbola. Tetapi, perlu ditekankan bahwa dunia hukum bidang olahraga tersebut tidak membentuk suatu dunia yang benarbenar terpisah dari negara.

Sebab, bagaimanapun juga jika aturan yang mengatur olahraga tersebut dibuat oleh organisasi-organisasi olahraga privat internasional, namunolahraga tetap saja tidak bisa menghindar dari penerapan hukum negara dimana olahraga tersebut

\footnotetext{
${ }^{11}$ Ibid, h. 175

${ }^{12}$ Ibid, h. 178.
}

dipertandingkan. Seperti perizinan keamanan, ketentuan pajak, ketentan pembentukan badan hukum bagi asosiasi dan klub, dan lain-lain.

\section{Sikap FIFA terhadap Undang-} Undang Ketenagakerjaan Suatu Negara

FIFA merupakan komunitas internasional yang melahirkan Lex Spportiva sebagai hukum transnasioanal yang hidup dan berlaku secara terus menerus dan diikuti oleh anggota-anggotanya, termasuk PSSI. FIFA sebagai salah satu federasi sepakbola internasional yang menaungi asosiasi-asosiasi sepakbola negaranegara seluruh dunia, FIFA memiliki kekuatan untuk menegakkan hukumnya sendiri. Misal, tim nasional indonesia dijatuh sanksi dilarang tampil di negara sendiri. Maka, negara tidak bisa ikut campur untuk membatalkan sanksi tersebut. Karena FIFA memiliki kekuatan tersendiri untuk menegakkan aturannya tanpa intervensi dari negara. Ini membuktikan bahwa adanya para subjek hukum non negara yang memiliki jangkauan pemberlakuan internasional dan diikuti secara interrnasional pula.

Lex Sportiva FIFAmengenai perjanjian kontrak antara pemain sepakbola profesional dengan klub dan kaitannya dengan hukum nasional suaatu negara, FIFA sendiri sebenarnya tidak menolak hukum ketenagakerjaan suatu negara, tetapi yang menjadi masalah adalah bagaimana jika hukum suatu negara bertentangan dengan Statuta FIFA dan peraturan-peraturan yang dibuat FIFA. Karena bagi "Football family" kekuatan hukum FIFA bisa lebih daripada hukum nasional.

Hal ini menjadi perhatian lebih lanjut berkaitan dengan perjanjian 
antara kontrak kerja antara pemain sepakbola profesional dengan klub di berbagai negara, terutama di Indonesia. Karena itu karekteristik utama bahwa Lex Sportiva merupakan peraturan kontraktual dengan kekuatan mengikatnya didasarkan pada perjanjian untuk menyerahkan kekuasaan dan hak kepada otoritas dan yuridiksi federasi olahraga internasional tersebut. Selain itu, "Lex Sportiva as a Global Sport Law tidak di atur oleh sistem hukum nasional". ${ }^{13}$ Dampak dari adanya Lex Sportiva FIFA mengenai perjanjian kerja ini terhadap perjanjian atau pemain sepakbola profesional dengan klub ialah adanya lembaga penyelesaian sengketa tersendiri yang tidak tunduk pada ketentuan hukum nasional. Pasal 68 Statuta FIFA 2011 menjelaskan bahwa:

1 The Confederation, Member, and Leagues shall agree to recognize CAS as an independent judical authority and to ensure that their members, affiliated Players, and Official comply whit he decisions passed by CAS. The same obligation shall apply to licensed macth and players' agents.

2 Recourse to ordinary courts of law is prohibited unless specifically provided for in the FIFA regulation. Recourse to ordinary courts of law for all types of provisional measures is also prohibited.

3 The Associations shall insert a clase in their statues or regulations, stipulating that it is prohibited to take disputes in the Associations or disputes affecting Leagues,member of Leagues, clubs, member of clubs,

\footnotetext{
${ }^{13}$ Ken Foster, oktober 2013,"is there a global
} sport law”, 16 oktober 2018, h.156.
Players, Official, and other Association Official to ordinary court of law, unless the FIFA regulation or binding legal provisions specifically provide for or stipulaterecourse to ordinary courts of law. Instead of recaurse to ordnary courts of law, the provisions shall be made for arbitration. Such disputes shall be taken to an independent and duly constituted arbitration tribunal recognized under therules of the Association or Confederation or to CAS. The Associations shall also ensure that this stipulation is implemented in the Association, if necessary by imposng a binding obligation on its members. The Association shall impose sanctions on any party that fails to respect this obligation and ensure that any appeal against such sunctions shall likewise be strictly submitetted to arbitration, and not to ordinary courts of law.

Berdasarkan rumusan pasal tersebut, dapat dijelaskan bahwa FIFA telah menyatakan bahwa setiap anggota tidak diperkenankan menyelesaikan sengketa melalui forum penyelesaian sengketa yang telah disediakan dalam statuta tersebut, seperti National Dispute Resolution Chamber, Dispute Resolution Chamber hingga yang paling tertinggi adalah Court of Arbitration for Sport yang berkedudukan di Swiss.

Disini keberlakuan UndangUndang Ketenagakerjaan tetap harus mempertimbangkan prinsip-prinsip khusus dalam hubungan kontrak pemain sepakbola yang disebutkan dalam RSTP tersebut dan peraturan yang lain. 


\section{Penyelesaian Sengketa Atlet Sepakbola Profesional}

Pemilihan forum penyelesaian sengketa atlet sepakbola profesional harus sesuai dengan kebutuhan para atlet dimana mereka menginginkan forum penyelesaian sengketa yang murah dan cepat yang tidak memakan waktu persidangan yang lama dan panjang. Dalam penyelesaian perselisihan antara atlet sepakbola dengan klub sepakbola, penulis akan menjelaskan beberapa forum penyelesaian sengketa untuk mengatasi permasalahan yang terjadi pada atlet sepakbola profesional.

Untuk menghormati apa yang ada dalam statuta FIFA dan statuta PSSI untuk mengindari penyelesaian melalui pengadilan dan menyelesaikan melalui lembaga arbitrase yang disediakan dalam statuta. forum penyelesaian sengketa olahraga dalam hal ini sepakbola profesional di Indonesia adalah CAS, Arbitrase PSSI dan Komisi Status Pemain PSSI.

\section{Court of Arbitrase for Sport (CAS)}

Arbitrase olahraga Internasional (CAS merupakan salah satu bentuk dari arbitrase institusional. CAS dibentuk dalam rangka untuk memfasilitasi menyelesaikan sengketa bisnis keolahragaan yang melingkupi klub, atlet-atlet, lembaga penyiaran, dan segala hal yang juga semua aktivitas yang berhubungan dengan olahraga.

\section{CAS.}

Ada beberapa keuntungan dari

Pertama, cocok untuk sengketa Internasional, ketika para pihak yang bersengketa tidak berdomisili di negara yang sama, akan timbul banyak masalah. Pertanyaan pertama yang harus dijawab adalah pengadilan mana yang berkopeten untuk memeriksa dan memutus, kemudian hukum mana yang dipergunakan. Para pihak di negara lain tentu akan kesulitan untuk menentukan bahasa dan prosedur di negara tersebut kerugian tersebut dapat dihindari dihadapan CAS.

Kedua, CAS didesain secara khusus untuk memfasilitasi penyelesaian sengketa yang berhubungan degan olahraga. sengketa yang berhubungan dengan olahragaserigkali bersifat kompleks dan membuthkan pengetahuan hukum secara khusus yang hakim pada umumnya tidak akan memilikinya. Para arbiter di CAS dipilih dari "daftar arbiter yang ditunjuk karena kompetensinya dbidang hukum dan pengetahuan tentang permasalahan yang berkaitan dengan aktivitas olahraga". ${ }^{14}$

Ketiga, CAS bersifat sederhana dan fleksibel, prosedur didisain unruk menghundari hal-hal yang berlebihan. Para pihak dapat ke CAS yang artinya pemohon membuat pernyartaan alasan secara singkat (Ordinary Procedure) atau melalui pernyataan sederhana mengenai banding (Appeal Prosedure). Pihak lawan kemudian menjelaskan posisinya dalam jawaban tertulis. Pertukaran tertulis kedua dapat di perintahkan kemudian. Pada akhirnya, para pihak dipanggil untuk proses hearing untuk pembuktian (mendengarkan saksi, keterangan ahli, dan lain-lain) dan untuk pembelaan lisan. Para pihak dapat secara bebas memilih para arbiternya melalui daftar yang dipublikasikan oleh CAS. Bahasa yang digunakan CAS adalah bahasa inggris dan prancis, yang keduanya sering digunakan dalam dunia olahraga. Bagaimanapun, para pihak

${ }^{14}$ Court Of Arbitration for Sport Guide to Arbitration. 
dimungkinkan dapat menyetujui untuk menggunakan bahasa lain selama proses. Para pihak dapat hadir sendiri dihadapan CAS atau dapat diwakilkan oleh wakilnya yang merupakan lawyer ataupun bukan.

Keempat, yaitu cepat,dalam bidang olahraga dibanding dengan bidang lainnya, penyelesaian sengketa harus segera diselesaikan. Karir atlet relatif singkat. Dia harus mampu mendapatkan keputusan dalam waktu yang singkat dalam sengketa dengan federasinya. Diwaktu yang bersamaan, federasi harus mampu untuk mengetahui seberapa cepat sengketa dapat diselesaikan. Jika perlu tanpa penundaan.

Kelima, disiapkan dalam Rangka Penyelesaian Tunggal. Lembaga peradilan umumnya mempunyai beberapa jenjang peradilan. (Peradilan Negri, Pengadilan Tinggi hingga Mahkamah Agung). Para pihak memiliki pilihan ke pengadilan lain jika mereka tidak setuju dengan putusan pengadilan ditingkat awal.

Sedangkan saat CAS menyatakan putusan hal itu bersifat final dan dapat ditegakkan. Meskipun terdapat hal-hal tertentu yang terbatas yang memungkinkan para pihak untuk banding.

Keenam, bersifat RahasiaTidak seperti prosedur pada umumnya, prosedur di CAS bersifat privat tanpa publik dan media mengetahuinya. Pada prinsipnya, proses hearing tidak diperbolehkan untuk publik dan media megetahuinya dan hanya para pihak yang menerima salinan putusan arbitrase. Kerahasiaan ini membantu untuk membentuk suasana yang tenang bagi penggugat, tergugat dan arbiter.

Ketujuh, salah satu tujuan CAS adalah menyediakan untuk para anggota di dunia keolahragaan suatu instrumen untuk menyelesaikan sengketa yang tidak hanya cepat tapi juga murah". 15 Dalam prosedur arbitrase biasa, para pihak membayar biaya untuk arbiter, pembagian biaya CAS, biaya saksi, ahli dan penerjemah. Disisi lain, dalam prosedur banding, biaya untuk arbiter dan CAS dibayar oleh CAS.

Prinsip dasar di CAS yaitu prinsip kebebasan menentukan pilihan forum arbitrase, para pihak memiliki kebebasan dalam melakukan pilihan forum (choice of forum) "Pilihan forum yang dimaksud semata-mata hanya menyangkut tentang pilihan bentuk arbitrase melaikan juga menyangkut tempat sidang arbitrase dilakukan". 16 Prinsip kebebasan menentukan pilihan hukum, para pihak yanfg tunduk pada hukum yang berbeda dalam membuat perjanjian bisnis dibidang olahraga memiliki kebebasan dalam melakukan pilihan hukum.

Jika para pihak tidak menentukan hukum yang dipakai, berdasarkan pasal $\mathrm{R} 45$ Statute and Regulation of Arbitration of The Court of Arbitration for Sport. Majelis atau panel akan menggunakan hukum Swiss. Kebebasan Menentukan Arbitor ,d alam hal ini para pihak yang bersengketa memiliki ekonomi yang luas untuk memilih siapa yang diangkat sebagai arbiter. Sudah barang tentu, arbiter dipilih terutama didasarkan pada pengetahuan dan keahlian yang dimilikinya sesuai dengan substasi sengketa sehingga menurut keyakinan pihak yang berperkara bahwa arbiter tersebut nantinya akan mampu menyelesaikan
${ }^{15}$ Adli, Loc. cit, h. 64 .
${ }^{16}$ Ibid, h. 50. 
sengketa dengan sebaikbaiknya.Prinsip sidang arbitrase bersifattertutup justru menegaskan sifat kerahasiaan penyelesaian sengketa secara arbitrase dan hal ini sesuai kehendak para pihak yang berperkara "Proses arbitrase hanya dapat dihadiri oleh pihak-pihakyang berperkara atau kasusnya, dan saksi-saksi". ${ }^{17}$ Mengenai prinsip kerahasiaan ini atau Confidentialy diatur dalam pasal R43 Statute and Regulation of Arbitration of The Court of Arbitration for Sport.

2. Badan Arbitrase PSSI

Badan arbitrase PSSI merupakan badan arbitrase yang dibentuk sendiri oleh PSSI berdasarkan surat Keputusan Nomor: SKEP/87/JAH/XI/2013 tentang Pembentukan Badan Arbitrase PSSI dan juga berdasarkan Pasal 69 statuta PSSI. Yurdiksi badan arbitrase PSSI di atur dalam Pasal 1 Regulasi Badan Arbitrase PSSI tentang peraturan dan acara arbitrase yang menyebutkan bahwa arbitrase PSSI mempunyai wewenang untuk menangani sengketa antar anggota PSSI, pemain, pelatih, agen pemain dan/atau agen pertandingan ataupun pihak ketiga yang berkepentingan yang tidak diatur dalam kode disiplin PSSI, kode etik PSSI dan badan yudisial adhoc PSSI maka para pihak wajib membawa sengketa yang timbul diantara mereka diantara arbitrase dihadapan badan arbitrase PSSI.dari pasal tersebut dapat disimpulkan bahwa segala sengketa yang diatur dalam kode disiplin PSSI .

Dari pasal tersebut dapat disimpulkan bahwa segala sengketa antar anggota PSSI, pemain, pelatih, agen pemain dan atau agen pertandingan maupun pihak ketiga

\footnotetext{
${ }^{17}$ Ibid.
}

yang berkepentingan yang tidak diatur dalam kode disiplin PSSI, kode etik PSSI dan Badan Yudisial ad-hoc PSSI harus dibawa terlebih dahulu ke arbitrase PSSI. Penyelesaian sengketa melalui badan arbitrase PSSI menghilangkan hak para pihak yang bersengketa untuk menyelesaikan perkara melalui Pengadilan Negeri dan merupakan instansi pertama yang berwenang mengadili sengketa sebagaimana dimaksud dalam pasal sebagaimana dimaksud Pasal 1 dan menimbulkan kewajiban untuk melaksanakan setiap putusan yang diambil oleh majelis Arbitrase berdasarkan peraturan prosedur PSSI, hal tersebut diatur dalam Pasal 2 Regulasi Badan Arbitrase PSSI tentang peraturan dan Acara Arbitrase.

3. Komosi Statuta Pemain PSSI

Kewenangan KomisiStatus pemain PSSI ini ada berdasarkan Pasal 23 Regulasi Status dan Transfer Pemain. Komisi status pemain mengadili kasus yang diuraikan dalam Pasal 22 dan juga sengketa lain yang timbul karena penerapan peraturan ini berdasarkan Pasal 24. Pasal 22 disebutkan bahwa, "Tanpa mengurangi hak tiap pemain atau klub untuk mengupayakan pada Pengadilan Hubungan Industrial, PSSI berwenang untuk mengadili: Sengketa antara klub dan pemain terkait dengan pelaksanaan dan implementasi kontrak (Pasal 13-18) yang mana telah ada permohonan ITC dan gugatan dari pihak yang berkepentingan terkait permohonan ITC tersebut, kususnya mengenai masalah ITC, sanksi olahraga atau kompensasi untuk pelanggaran kontrak; Sengketa hubungan industrial antara klub dan pemain dalam lingkup nasional dengan melakukan proses pemeriksaan yang adil dan menjunjung 
prinsip persamaan keterwakilan pemain dan klub;

Sengketa hubungan industrial antara klub atau asosiasi dan pelatih dalam lingkup nasional".

Kemudian Pasal 23 menyebutkan bahwa, "Komosi status pemain mengadili kasus yang diuraikan dalam Pasal 22 dan juga sengketa lain yang tmbul karena penerapan peraturan ini, berdasarkan Pasal 24. Komosi status pemain mengadili dengan dihasiri paling sedikit tiga anggota, termasuk ketua atau wakil ketua, kecuali kasus tersebut pada dasarnya dapat diadili oleh hakim tunggal. Perkara yang dapat diadili oleh hakim tunggal adalah perkara dalam hal terdapat hal yang mendesak atau tidak terdapat isu hukum atau fakta yang sulit, dan untuk keputusan terhadap pendaftaran sementara pemain sehubungan dengan izin Internasional sesuai dengan, pasal8, ketua atau orang yang ditunjuk olehnya, yang harus merpakan anggota komodi, dapat mengadili sebagai hakim tunggal.

Setiap pihak wajib didengar minimal satu kali dalam pemeriksaandenan menjunjung tinggi asas impersonal dan impersial. Dari beberapa lembaga peyelesaian sengketa yang tersedia, pemain sepakbola dapat menyelesaikan sengketa melalui arbitrase yang disediakan oleh FIFA dan PSSI berdasarkan kewenangan dan yuridiksi masing-masing forum penyelesaian sengketa,. Karena dibanding dengan Pengadilan Hubungan Industrial, penyelesaian sengketa lewat arbitrase yang disediakan

Oleh FIFA maupun PSSI dapat selesai lebih cepat, lebih paham sekaligus mempunyai pengetahuan lebih untuk meyelesaikan sengketa dibanding keolahragaan. Cepat inilah yang dibutuhkan pemain karena pemain dikejar dengan masa berakhirnya jeda kompetisi yang hanya sekitar 2-3 bulan saja.

Pada Pasal 21 mengenai Arbitrase, disebutkan bahwa apabila terjadi perselisihan maka para pihak menyelesaikan sengketa secara musyawarah mufakat dalam jangka waktu 30 hari. Jika gagal, maka para pihak memilih BAKI sebagai lembaga penyeleaian sengketa. Untuk pemain asing, jika terjadi segketa dapat menyelesaikan melalui Komite Alih Status dan Transfer PSSI dan/atau BAKI dapat mengajukan peninjauan kepada DRC FIFA dan jika tidak puas dengan keputusan DRC FIFA dapat mengajuan peninjauan kembali kepada CAS. Pemilihan BAKI dalam penyelesaian sengketa kontrak pemain tersebut cukup beralasan karena pada saat itu belum terdapat lembaga arbitrase lain yang berkompeten menyelesaikan sengketa pemain lokal ditingkat nasional.

Jika pemain nekat menyelesaikan sengketa melalui Pengadilan Hubungan Industrial, kemungkinan juga akan ditolak karena para pihak dalam kontraknya sudah terdapat klausul arbitrase dengan memilih BAKI sebagai forum penyelesaian sengketa. Maka, diharapkan dengan adanya arbitrase PSSI saat ini dapat menjawab problematika tersebut, karena dengan membentuk penyelesaian sengketa yang cepat, sederhana dan murah adalah kewajiban PSSI untuk melindungi anggotanya dan mensejahterakan pemain dan klub dan juga majunya prestasi oahraga Indonesia.

Sehingga, pemilihan forum penyelesaian sengketa pemain dan klub sepakbola kembali lagi pada isi klausul 
penyelesaian sengketa dalam masingmasing kontraknya. Apakah memilih Pengadilan Hubungan Industrial ataukah memilih forum penyelesaian sengketa yang disediakan oleh FIFA maupun asoaiasi sepakbola masingmasing negara.

\section{KESIMPULAN}

Pemain sepakbola tunduk pada Ketentuan FIFA dan Undang-Undang Nomor 3 Tahun 2005 tentang Sistem Keolahragaan Nasional. UndangUndang Nomor 3 Tahun 2005 tentang Sistem Keolahragaan Nasional merupakan Lex Specialis dari UndangUndang Nomor 13 Tahun 2003 tentang Ketenagakerjaan. Maka, ketentuan yang mengatur hubungan kerja antara pemain sepakbola dengan klub sepakbola profesional di Indonesia adalah hukum olahraga Lex Sortiva.

Terdapat kelemahan jika memberlakukan Undang-Undang Ketenagakerjaan semata tanpa memperhatikan dan mengakui peraturan FIFA dan PSSI. Karena akan terdapat kekosongan hukum dimana tidak ada hal-hal yang diatur baik didalam Undang-Undang Ketenagakerjaan dan konflik norma antara sistem hukum nasional dengan sistem hukum olahraga (Lex Sportiva). Seperti, hubungan hak dan kewajiban antara PSSI, klub dan pemain sepakbola dalam hal pemanggilan pemain ke tim nasional, waktu kerja pemain sepakbola profesinal, hukum nasional tidak dapat menjatuhkan sanksi olahraga (Sport Sanction) terhadap klub, ketentuan mengenai Training compensation dan solidarity mechanism dan hukum yang dipakai jika menyelesaikan sengketa pemain sepakbola dengan klub melalui Pengadilan Hubungan Industrial. Dengan berbagai kekurangan tersebut
Meskipun secara legal-formal tetap tunduk pada Undang-Undang Ketenagakerjaan, sebenarnya tidak ada masalah, karena perlindungan pemain sepakbola telah diatur dalam berbagai peraturan FIFA dan PSSI. Dan forum penyelesaian sengketa antara pemain sepakbola profesional dengan klub sepakbola dan juga berdasarkan Pasal 88 ayat 3 Undang-Undang Sistem Keolahragaan Nasional tentang penyelesaian sengketa melalui badan arbitrase yang telah di tentukan oleh organisasi olahraga yang bersangkutan (FIFA atau PSSI).

\section{E. DAFTAR BACAAN}

\section{Buku-Buku}

Asyhadie, Zaeni.Hukum Kerja Hukum Ketenagakerjaan Bidang Hubungan Kerja, cet. 3. Jakarta; PT. RajaGrafindoPersada. 2013.

Mahmud, Memet, Momon Sudarman dan Ujang Sudrajat. Sport Marketing. Bandung; laksitas Graha Ilmu. 2010.

Melialala, Djaja, S. Hukum Perdata Dalam Perspektif $B W$, Bandung, NuasaAulia, 2012.

Subekti. Hukum Perjanjian. cet. 12. Jakarta; PT. Intermasa. 1987.

Panjaitan, Ip Hinca, Kedaulatan Negara VS Kedaulatan FIFA. Jakarta; Gramedia Pustaka Utama. 2011.

\section{Perundang-undangan}

Court Of Arbitration for Sport Guide to Arbitration.

Undang-undang Dasar Negara Republik Indonesia Tahun 1945

Subekti, R dan R. Tjitrosudibio. Kitab Undang-Undang Hukum Perdata.cet. 37. Jakarta: PT Prajaya Pramita. 
Undang-Undang Nomor 3 Tahun 2005

Tentang Sistem Keolahragaan

Nasional. LN No.89 tahun 2005.

TLN No. 4535

Undang-Undang Nomor 13 Tahun 2003 Tentang Ketenagakerjaan. Media Center

FIFA, Regulation on the Status and Transfer of Players.

Regulasi Statuta PSSI

\section{Skripsi-Skripsi}

Rahmasari, Dita, "Analisis Yuridis Perpindahan Pemain Sepakbola Berdasarkan Kitab UndangUndang Hukum Perdata dan Peraturan Keolahragaan Lainnya" Program Studi Pascasarjana Universitas Indonesia, Depok, Juni 2011.

Parulian Aruan, Hotman Bintang, " Berlakunya Statuta Federation Internationale de Football Association(FIFA) Terhadap Kedaulatan Negara Studi Kasus Dualisme Persatuan Sepakbola Seluruh Indonesia (PSSI)". Program Studi Pascasarjana Universitas Sumatera Urtara, Medan, Januari 2014.

Firdandhi Lutfi Putra, Abdul Salam, Togi Pangaribuan, "Perlindungan Hukum Bagi Pemain Sepakbola Atas Permasalahan Perjanjian Kerja Dengan Klub Sepakbola Profesional" Program Studi Pascasarjana Universitas Indonesia, Jakarta, 2014

Adli, Ashari Setya Marwah, "Kontrak Kerja Pemain Sepakbola Profesional dengan Klub Sepakbola Di Indonesia" Program Studi Pascasarjana Universitas Airlangga, Surabaya, 2015. 